\title{
В. О.Туляков
}

\section{ТЕНДЕНЦї̈ КРИМІНАЛЬНОї ПОЛ ІТИКИ УКРАЇНИ ТА ДЕЯКі ІІНСТИТУТИ СУЧАСНОГО ЗАКОНОДАВСТВА}

Динаміка кримінального права виступає як процес правореализації шляхом примусового чи вільного використання, виконання, не порушення, застосування правової заборони, а також як процес формування та інтерпретації кримінально-правових норм у відповідності із потребами суспільного розвитку та панівною науковою концепцією (ідеологією).

Отже у сучасних умовах динаміка кримінального права визначає процес постійного становлення та розвитку, відтворення кримінальноправових заборон шляхом кардинальних (чи інтерпретаційних) змін у правовому регулюванні. 3 цього боку формування правового хаосу $\epsilon$ невід'ємною частиною розвитку взаємодії між кримінальним правом та суспільством за умов динамічних та не завжди послідовних новацій у системі кримінально-правового реагування, що відображують очікування керуючої еліти та лише обмежним чином потреби суспільства у почутті власної безпеки.

Відомо, що і принцип свободи волі класичної школи Ч. Беккаріа та İ. Бентама, і шанований на пострадянському просторі економічний детермінізм К. Маркса і його послідовників, і психоаналіз 3. Фрейда, і багатовекторний підхід Ч. Ломброзо - $€$ не що інше як спроби певним чином абсолютизувати знайдені певні закономірності проявів соціуму у кримінально-правових реаліях. Панівна соціальна теорія знаходить своє визначення у відповідних кримінально-правових нормах. За таких умов ми спроможні описати співвідношення кримінально-правових заборон 3 іншими нормами, визначити буття кримінально-правової норми у сфері як права, так і закону з урахуванням панівної соціальної теорії та лише стосовно поточного історичного моменту.

Найяскравіше це проявляється в існуючих концептах пунітивної юстиції, ресторативної юстиції і віджилантізму (аболіціонізму). 
Відомо і традиційно зрозуміло, що захист суспільства від злочинців повинен здійснюватися за допомогою застосування до останніх жорстких і невідворотних покарань (пунітивний підхід).

Відповідні зміни у суспільній свідомості висунули на перший план проблему «юстиції причетних», у межах якої воля потерпілого посідає центральне місце. Проблема ролі «відновлювальної юстиції» (restorative justice) у взаємовідносинах правопорушника i його жертви, а також у процесі профілактики злочинів була однією із центральних тем X i XI Конгресів ООН з попередження злочинності і поводження із правопорушниками (2000, 2005 рр.). Згідно із даним підходом, ідея взаємної відповідальності громадянина і держави реалізується тоді і остільки, коли і оскільки держава не просто захищає громадян системою правових приписів-регуляторів, але і несе відповідальність, якщо хто-небудь такі приписи порушив.

Нарешті, наявність інституту посередників між потерпілим і злочинцем, людей, чиїм основним зайняттям $\epsilon$ «роздача болю» (Н. Крісті), будучи настільки затребуваною в епоху абсолютизму і наступні століття, виявилася не зовсім потрібною чи навіть неузгодженою із природними правами окремих індивідів у XXI ст.

Система правосуддя буксує, суди переповнені справами, правоохоронні органи незалежно від рівня злочинності завжди працюють на межі можливого, зростає рівень призоніцації населення.

У цих умовах виникає третя сила - рух, спрямований на необхідність самостійного відправлення правосуддя, на легалізацію самосудів і обмеження застосування норм кримінального права як єдиного регулятора системи найнебезпечніших девіацій (аболіціонізм).

Насправді жоден з цих підходів не існує у чистому вигляді. Ефект «майданів» та «врадієвки» саме підтверджує це. Дисфункції соціальних інститутів у сфері забезпечення природних прав і свобод людини і громадянина $€$ каталізаторами активації права на повстання та легалізації самосуду. Виникає ситуація, прозоро визначена Пітірімом Сорокіним 100 років тому. «Фактично майже у будь-якому суспільстві акти, що вважаються злочинними з юридичної... точки зору, зовсім не $є$ такими з точки зору всіх членів суспільства; так само юридичний захист через покарання тих чи інших злочинців не рівнозначний захисту усього суспільства, а являє собою лише захист його привілейованої частини... захист, який для інших елементів суспільства суцільно постає простими утисками, насильством, і, якщо завгодно, злочином» [1].

В умовах стагнації застосування пунітивного підходу забезпечує стабільність існування влади.

Розвиток потребує використання гуманістичних елементів кримінально-правової регуляції.

Безумовно, усе це потребує відповідного наукового аналізу та встановлення можливостей його використання для гармонізації кримінальноправових заборон із характеристиками сучасного суспільства. Поруч 
з цим питання аналізу характеристик кримінальної політики не можуть отримати відповідного підгрунття в епоху постмодерну та панування аномії, правового нігілізму у повсякденних подіях, оскільки еклектизм стає ідеологією повсякденної законотворчості.

Питання, чи необхідна нам зміна Кримінального кодексу сьогодні, отримує вочевидь негативну відповідь. Справа у тому, що адитивна функція кримінально-правових заборон пов'язує необхідність змін кримінального законодавства зі змінами суто конституційних норм чи апроксимацією закону із відповідними ратифікованими міжнародно-правовими договорами.

В транзитивному суспільстві відбувається перехід та розвиток від однієї нормативної моделі (соціалістична правова родина) до іншої (романо-германська) з елементами соціокультурного буття слов'янської чи візантійської моделі (Ю. М. Оборотов). Процес цей має бути достатньо довгим насамперед у галузі публічно-правової регуляції.

Два основних його елементи: гуманізація та таксономія.

I саме останнє є завданням більшості криміналістів сьогодення, бо пов'язане із формуванням ідей розподілу та категоризації кримінальних правопорушень, підготовки кодексу кримінальних поступків.

Зазначимо, що Одеська кримінально-правова школа виходить із констатації необхідності існування єдиного Кримінального кодексу, у якому кримінальні правопорушення (злочини та проступки) відрізнялися би за ступенем тяжкості та заходами кримінально-правового реагування. Злочинам кореспондували би покарання, кримінальним проступкам - кримінальні стягнення.

При чому Кримінальний кодекс нового типу як «негативна конституція країни» повинен передбачати відповідальність виключно за «природні» злочини, злочини, сутність яких витікає не з системного доктринального аналізу суспільної небезпеки діяння, а з логіки захисту конституційних принципів чи, як записано в Конвенції про захист прав людини та основних свобод, - «загальних принципів права, що визнані цивілізованими країнами» (ч. 2 ст. 7 ).

Безумовно, це вимагає нового вирішення питання сутності і характеристик кримінальної відповідальності та форм iï реалізації, кримінальноправових відносин та їх суб’єктів та ін.

Тобто в Загальній частині нового КK повинне бути зроблено відокремлення інституту злочинів та проступків, потерпілого від злочину, концепції шкідливого стану злочинця, покарання та заходів кримінальноправового впливу (заходи безпеки, соціального захисту, заходи компенсаціï), кримінально-правових стягнень.

В найбільш спрощеному вигляді система Особливої частини такого KК повинна була б включати до себе щонайменше два розділи: Злочини проти фізичних чи юридичних осіб, їхніх прав та свобод, Злочини проти суспільства або держави (ч. 2 ст. 11 діючого KK). Причому пропонується не відокремлювати книгу про проступки, а гармонічно «вписати» їі у 
тіло Особливої частини, зробивши, наприклад, системним принципом формування Кодексу модель, за якою привілейовані та більшість простих складів правопорушень можуть бути віднесеними до кримінальних проступків, а кваліфіковані склади - до злочинів. Відповідно, згідно 3 категоризацією за ступенем тяжкості, до злочинів були б віднесені особливо тяжкі та тяжкі кримінальні правопорушення та правопорушення середньої тяжкості, які посягають на особу та їі основні права та фундаментальні свободи.

Аналіз останніх змін та доповнень Кримінального Кодексу свідчить саме про такій підхід. Так, Законом «Про внесення змін до деяких законодавчих актів України щодо виконання Плану дій щодо лібералізації Європейським Союзом візового режиму для України» від 23.05.2013 № 314-VII [2] в Україні вводиться інститут кримінальної відповідальності юридичних осіб. Не торкаючись достатньо дискусійної з точки зору слов'янської правової родини ідеї, відмітимо, що питання примусу у даному законі відрегульовано через концепт заходів. Так, згідно зі ст. $96^{2} \mathrm{KK}$ до юридичних осіб судом можуть бути застосовані такі заходи кримінальноправового характеру як штраф, конфіскація майна та ліквідація.

Отже, залежно від виду, ступеню тяжкості кримінального правопорушення та характеристики суб'єкта правопорушення до нього можуть бути застосовані чи покарання, чи інші кримінально-правові заходи примусового характеру.

І̇снування інституту заходів кримінально-правового характеру (О. В. Козаченко), їх подальша диверсифікація вимагають негайного вирішення ще однієї проблеми. Це стосується визначення в Загальній частині КК України правової природи спеціальної конфіскації, вилучення та знищення предметів, які не $€$ заходами кримінального покарання.

3 нашої точки зору, таке нормативне визначення надасть доцільну та обгрунтовану можливість призначення (не використовуючи елементи аналогії права) та застосування вказаних заходів не тільки для кримінальних правопорушників, але й до осіб, щодо яких не застосовується кримінальне покарання (неповнолітні, що мають власне майно, особи, звільнені від кримінального покарання).

Протягом останніх років питання законності застосування заходів конфіскації як покарання, проблемні питання теоретичного та практичного застосування існуючих заходів «спеціальної конфіскації» за КК України, правова природа заходів «спеціальної конфіскації» та вилучення майна, передбачених в якості додаткового кримінально-правового заходу за низкою санкцій статей Особливої частини КК України, розмежування заходів конфіскації та «спеціальної конфіскації», передбаченої Кримінальним кодексом України та Кримінальним процесуальним кодексом України, стали предметом дослідження спеціалістів кафедри кримінального права НУ «Одеська юридична академія» [3].

3 нашої точки зору, система кримінально-правових заходів поруч 3 покаранням може бути представлена сукупністю додаткових заходів 
державного примусу, які застосовуються виключно судом та передбачені кримінальним законом.

Серед таких заходів захисту суспільства від небезпечних зазіхань в сучасному світі широко розповсюджені кримінально-правові заходи безпеки, до яких низка закордонних країн саме відносить заходи спеціальної конфіскації.

Заходи безпеки, за своєю сутністю, - примусові заходи попереджувального впливу, які застосовуються до особи, яка скоїла суспільно небезпечне злочинне діяння, згідно з законом за рішенням суду та за наявності в законі підстав, з метою обмеження певних можливостей рецидиву з боку даної особи чи загально спеціального попередження злочинів (ситуативна профілактика)

При чому заходи безпеки можуть застосовуватися як поряд з покаранням, так і замість нього. Застосування заходів безпеки в профілактиці злочинності має досить ефективний вплив, що було відзначено світовою спільнотою і рекомендовано до застосування.

Кримінальне законодавство сучасних країн світу вбачає ефективність протидії злочинності не тільки у застосуванні кримінального покарання. В кримінальному праві сучасності напрацьовується практика багатоколійності кримінально-правових наслідків, тобто поруч із покаранням широкого застосування набувають кримінально-правові заходи безпеки, компенсаційні заходи та заходи примирення (або медіації). Можливість поєднання і комплексного застосування таких кримінально-правових заходів створює міцний та ефективний механізм у протидії злочинності.

Стосовно спеціальної конфіскації.

Спеціальна конфіскація в КК України передбачена 34 статтями Особливої частини KK, і все ж таки варто відмітити, що спеціальну конфіскацію як захід безпеки з метою попередження скоєння нових злочинів потрібно ввести до норм, що передбачають відповідальність за ст. $185 \mathrm{KK}$ - крадіжка (ч. 1, 2), ст. 186 KK - грабіж (конфіскація незаконно отриманого майна, коштів), ст. $198 \mathrm{KK}$ - придбання, отримання, зберігання або збут майна, здобутого злочинним шляхом, ст. 200 KK - незаконні дії з документами на переказ, платіжними картками та іншими засобами доступу до банківських рахунків, обладнанням для їх виготовлення (конфіскація документів, платіжних карток, обладнання), ст. 203-1 КК України - порушення законодавства, що регулює виробництво, експорт, імпорт дисків для обладнання або сировина для їх виробництва, ст. 207 KК - ухилення від повернення виручки в іноземній валюті (конфіскація незаконно набутих коштів, майна та одержаних від цього прибутків), ст. $212 \mathrm{KK}$ ухилення від сплати податків, зборів та інших обов'язкових платежів (спеціальна конфіскація прибутку, отриманого з вказаних коштів), ст. $213 \mathrm{KK}$ - порушення порядку здійснення операцій з металобрухтом (конфіскація коштів, отриманих від реалізації металобрухту та самого металобрухту). Це $є$ саме формою реалізації принципу ціле- 
спрямованої репресивності, що вимагає диверсифікації заходів кримінально-правового впливу [4].

Ще одне питання, яке виникає при аналізі сучасних положень кримінальної політики України, стосується окремих характеристик інституту помилування.

Помилування як інститут звільнення від відбування покарання має достатньо довгу історію та різні форми реалізації у відповідних правових родинах [5]. Професор Джефрі Кроуч, аналізуючи проблему помилування в США, вказує, що інститут помилування за своєю основою та формами реалізації $€$ суто політичним. Заважаючи на те, що ці президентські повноваження (відстрочка виконання вироку, умовне помилування, звільнення від фінансових стягнень, звільнення від відбування покарання, заміна покарання більш м'яким) встановлено у Конституції США, використання помилування здійснюється як політичний акт та грунтується на політичних передумовах. Кроуч [6] вказує на наступні парадокси інституту помилування у президентів США:

перший, пов'язаний із тенденцією скорочення кількості випадків застосування помилування, при існуванні необмеженого кола можливостей зробити це. Найбільше ця тенденція проявляється у останній перед наступними виборами рік;

другий, пов'язаний із типовими для американської політичної системи вельми ризиковими актами помилування за справами, які набули політичного резонансу. В результаті, за умов можливості використання права на помилування як політичної зброї чи елементу зловживання владою, помилування загально-кримінальних злочинців характеризувалося більшим ступенем легітимності, ніж помилування, обумовлене особистими політичними мотивами.

Звернемо увагу, що аналізовані позиції мають відношення виключно до американської системи та використані нами для прикладу типовості складності та полісистемності застосування інституту помилування в країнах світу, в тому числі й в Україні.

До того ж президентське конституційне право помилування не $є$ предметом виключно кримінально-правового регулювання і на практиці пов'язане із процесом, який у більшості країн неможливо охарактеризувати як доступний та справедливий. Саме політична мотивованість, закритість, непрозорість цього процесу надає можливість широкої критики його здійснення у різних юрисдикціях.

Але питання парадоксів помилування пов'язане не тільки із характеристиками його політичної складової, а й саме із тими, що належать до кримінально-правової площини.

Діюча правова доктрина України (В. Гончаренко, А. Гришко, Т. Дуюнова, В. Сердюк, А. Музика, Є. Письменський, С. Школа, О. Чепелюк, О. Ус) відносить акт помилування до виду дострокового звільнення від відбування покарання. Згідно з положенням ст. 87 Кримінального кодексу України помилування здійснюється Президентом України стосовно 
індивідуально визначеної особи. Причому актом про помилування може бути здійснена заміна засудженому призначеного судом покарання у виді довічного позбавлення волі на позбавлення волі на строк не менше двадцяти п'яти років.

Відповідно Положенням про порядок здійснення помилування від 16 вересня 2010 року встановлено, що помилування засуджених здійснюється у виді: заміни довічного позбавлення волі на позбавлення волі на строк не менше двадцяти п'яти років; повного або часткового звільнення від відбування як основного, так і додаткового покарання; заміни покарання або невідбутої його частини більш м'яким покаранням.

Тобто актом про помилування засуджена особа може бути звільнена від відбування покарання, чи покарання (невідбута його частина) може бути замінене більш м'яким покаранням.

В цьому сенсі виникає питання - що мав на увазі законодавець, відокремлюючи процедуру помилування осіб, які були засуджені до довічного позбавлення волі, в особливий вид?

Дана проблема не отримала необхідного аналізу, оскільки очевидно, що з точки зору більшості науковців та правозастосовної практики у ч. 2 ст. 87 KК мова йде про заміну покарання у вигляді довічного позбавлення волі іншим більш м'яким покаранням. Але все ж таки, навіщо ми спеціально підкреслюємо особливий характер та умови такого звільнення від відбування покарання?

3 одного боку, подібні правила існують у міжнародній практиці. Так, ст. 110 Римського Статуту Міжнародного Кримінального Суду дозволяє перегляд покарання у вигляді позбавлення волі з метою його скорочення робити лише після відбуття 25 років ув'язнення. Скорочення терміну ув'язнення осіб, яких засуджено до довічного позбавлення волі, передбачено після відбуття засудженими терміну не менше ніж 20-25 років законодавством Австрії, Бельгії, Німеччини, Польщі, Росії, Туреччини [7]. Наприклад, ст. 79 КК Російської Федерації пов’язує можливість умовно дострокового звільнення від відбування довічного позбавлення волі з фактичним відбуттям особою терміну не менше як 25 років [8].

Проте мова йде у відзначених випадках дострокового звільнення від відбування довічного позбавлення волі про прерогативу суду, а не про спеціальне повноваження органу виконавчої влади, оскільки за загальним правилом президент має право на помилування будь-якої особи.

Питання відокремлення заміни довічного позбавлення волі на позбавлення волі на певний строк шляхом помилування в Україні має два юридичних парадокси.

Перший: спеціальна норма, обмежуюча можливості застосування та характеристики помилування осіб, засуджених до довічного позбавлення волі, розміщується перед загальною. В тексті закону та інших нормативних актів заміна покарання у вигляді довічного позбавлення волі позбавленням волі на строк не менше 25 років відокремлюється особливо. Це говорить не тільки про спеціальний характер цього виду звільнення від 
покарання, але й про певні процесуальні особливості. Сказане підтверджується характеристиками призначення цієї форми заміни та спеціальним порядком відбування позбавлення волі.

Так, Кримінально-виконавчий кодекс України та Положення про порядок здійснення помилування встановлюють особливу процедуру подання клопотання про помилування засуджених до довічного позбавлення волі.

Відомо, що «засуджений до довічного позбавлення волі має можливість після фактичного відбуття не менше 20 років покарання подати до Президента України клопотання про помилування. У разі помилування визначене засудженому покарання заміняється позбавленням волі на певний строк, але не менше двадцяти п'яти років». Після заміни покарання у вигляді довічного позбавлення волі позбавленням волі на строк не менше 25 років є можливість (згідно із ч. 5 ст. 82 КК України та думкою більшості криміналістів) застосувати до засудженого умовнодострокове звільнення. До того ж, згідно зі ст. 140 КВК України чоловіки, яким покарання у виді довічного позбавлення волі замінено позбавленням волі на певний строк у порядку помилування, утримуються в умовах суворої ізоляції у звичайних жилих приміщеннях у виправних колоніях максимального рівня безпеки.

Другий: у ст. 87 КК України було сформульовано підстави оформлення невідомого українській кримінально-правовій теорії заходу у вигляді позбавлення волі, який оцінюється як покарання у вигляді позбавлення волі на певний строк. Лексична характеристика положень ч. 2 ст. 87 KК дає можливість стверджувати, що законодавець певним чином відокремлює «заміну позбавленням волі» від «заміни покаранням у вигляді позбавлення волі». Хоча, відверто кажучи, термін «замість позбавлення волі» використовується також у ч. 2 ст. 62 КК України, коли мова йде про тримання у дисциплінарному батальйоні військовослужбовців.

Заміна покарання у вигляді довічного позбавлення волі позбавленням волі на певний строк лексично зустрічається і можлива у разі незастосування судом давності виконання обвинувального вироку (ч. 5 ст. 80 КK). Але на відміну від ситуації, передбаченої ч. 2 ст. 87 KК, ця заміна покарання іншим, більш м'яким покаранням проводиться судом відповідно до положень ст. ст. 65, 69 KК. Тобто саме суд, а не орган виконавчої влади, прозоро із застосуванням відповідних процесуальних гарантій та правил призначення (заміни) покарання вирішує можливість заміни одного покарання іншим.

У випадку заміни покарання у вигляді довічного позбавлення волі позбавленням волі на певний строк у порядку помилування ми зустрічаємося:

з особливим порядком набуття права на помилування,

з особливим порядком призначення кримінально-правового заходу,

з особливим терміном його призначення (згідно з діючим законодавством України суд не в змозі призначити покарання, яке перевищує 25 років позбавлення волі. Водночас положення ч. 2 ст. 87 KК дозволя- 
ють Президентові заміняти покарання у вигляді довічного позбавлення волі заходом, який не може бути менший 25 років),

з особливим порядком його виконання.

Отже, ізоляція засудженого та поміщення його на певний строк до кримінально-виконавчої установи за ініціативою Президента у порядку помилування на термін, який перевищує 25 років, носить самостійний правовий характер та може бути визначеною як особливий кримінальноправовий захід.

А саме - захід безпеки у вигляді превентивного позбавлення волі (поруч із спеціальною конфіскацією, вилученням з обігу та знищенням предметів злочину, позбавленням чи обмеженням в правах, наглядом, тощо, примусовими заходами медичного та виховного характеру та примусовим лікуванням, що застосовується до неповнолітніх чи обмежено осудних осіб). До речі, такий відмінний від покарання захід - превентивне позбавлення волі - був відомий законодавству Німеччини, але у 2011 році Конституційний суд Німеччини слідом за Європейським судом з прав людини визнав сутність та процедуру призначення такого ув'язнення незаконним.

Так, за даними видання «Закон і Бізнес», превентивного ув’язнення зазнають злочинці, відносно яких у властей існують побоювання, що, опинившись на волі, вони скоять нові злочини. До 1998 року максимальний строк превентивного ув'язнення в ФРН становив 10 років, проте потім влада отримала право продовжувати його заднім числом на невизначений час. Визнавши превентивне ув'язнення незаконним, у травні 2011 р. Конституційний суд ФРН відзначив, що воно несумісне з фундаментальним правом арештантів на волю. Представники суду підкреслили, що таке ув'язнення (міра, суть якої - захистити населення від злочинців) фактично нічим не відрізняється від покарання у вигляді позбавлення волі. Конституційний суд вимагає від властей до червня 2013 року подати нову концепцію ставлення до злочинців, орієнтовану на їх терапевтичне лікування і подальше звільнення [9].

Можливо, певний сенс у доктринальному розв'язанні цієї проблеми у майбутньому надають положення рішення Європейського суду з прав людини у справі п. Дель Ріо Прада проти І̇спанії від 21.10.2013р., № 42750/09 [10]. У цій справі вперше особливо обговорювалися питання розбіжностей між покаранням та відбуванням покарання в сенсі практики складання покарань, що були призначені за сукупністю вироків.

Громадянку Дель Ріо Прада було засуджено за злочини, пов’язані 3 тероризмом, на термін понад 3000 років та призначене остаточне відбування позбавлення волі на 30 років. Згідно новій доктрині, що застосовується у І̇спанії проти терористів, членів організованих злочинних угрупувань кримінальний закон розрізняє термін «покарання»та «виконання покарання» у сенсі його складання, поглинання чи/або заміни. Мова йде про те, що остаточний термін відбування покарання, призначений за су- 
купністю вироків, не $є$ покаранням, а лише терміном, оскільки саме покарання та конкретні строки визначаються судом за кожен окремий вчинок та повинні рахуватися окремо при застосуванні процедур умовно-дострокового звільнення від покарання.

Аналізуючи це, Європейський суд дійшов висновку, що певна різниця, хоча й недостатньо чітка (п. 85 рішення) існує між концептом «покарання» та концептом «виконання покарання»у кримінально-правовому сенсі. У п. 90 рішення Суд особливо визначає, що, аналізуючи правову природу відбування покарання чи самостійних характеристик відповідних кримінально-правових заходів, треба виходити із особливостей характеристик національного матеріального права.

3 цього боку та виходячи з наведених вище аргументів, вважається можливою постановка питання про розгляд позбавлення волі на строк більше 25 років, яке застосовується за указом Президента України про помилування у якості заміни довічного позбавлення волі, в силу особливих нормативних, процесуальних, та правореалізаційних характеристик як особливого кримінально-правового заходу, та, можливо, як спеціального виду реалізації кримінальної відповідальності.

Зрозуміло, що питання носить достатньо дискусійний, якщо не парадоксальний характер, проте поступовий перехід системи нашої кримінальної юстиції на «багатоколійний» простір (що підтверджують останні зміни до $\mathrm{KK}$, пов'язані із нормативним закріпленням окремих кримінально-правових заходів) надає можливість розглянути його у майбутньому.

Розв'язання цього питання можливе у трьох напрямках: редакційне уточнення положень ч. 5 ст. 80 та ч. 2 ст. 87 KК; виключення ч. 2 ст. 87 КК та надання права суду згідно зі ст. 82 на заміну довічного позбавлення волі покаранням у вигляді позбавлення волі на термін не менший як 25 років; розвиток концепції призначення покарання та інших кримінально-правових заходів (безпеки, соціального захисту, реституції та компенсації, превенції, заохочування) та їх нормативне закріплення у законодавстві про кримінальні правопорушення України.

Саме в останньому бачиться (поруч із послідовним вирішенням питання про кримінальні правопорушення та їх таксономічним розподілом) перспективний напрямок розвитку кримінально-правової політики України.

\section{Л і те р а т у р а}

1. Сорокин П. Наказание и кара, подвиг и награда. Социологический этюд о формах общественного поведения и морали / Питирим Сорокин. - СПб., 1914. - С. 79.

2. http://zakon3.rada.gov.ua/laws/show/314-18.

3. Туляков В. О. Заходи безпеки в системі засобів протидії організованій злочинності / В. О. Туляков // Науковий вісник Львівського юридичного інституту МВС України. - 2005. - № 2. - С. 45-50; Чугуников Іे. І̇. Конфіскація майна / і́. İ. Чугуников // Юридична енциклопедія для юнацтва. - O., 2006. - C. 191-192; Горбачова Іे. М. Дотримання прав людини при застосуванні до винної особи заходів спеціальної конфіскації за чинним КК України / İ. М. Горбачова // Боротьба зі злочинністю та 
права людини : зб. наук. ст. / за ред. М. П. Орзіха, В. М. Дрьоміна. - О., 2006. С. 112-117; Горбачова İ. М. Розмежування конфіскації і спеціальної конфіскації / I. М. Горбачова // Актуальні проблеми держави і права: зб. наук. пр. - О., 2007. - Вип. 32. - С. 182-186.

4. Багрий-Шахматов Л. В. Уголовная ответственность и наказание / Л. В. Багрий-Шахматов. - Минск, 1976. - С. 268.

5. Письменський Є. О. Звільнення від покарання та його відбування: проблеми кримінального законодавства та практики його застосування / Є. О. Письменський. Луганськ, 2011 - С. 268-285.

6. Crouch J. The Presidential Pardon Power / Jeffrey Crouch. - Lawrence, Kansas: University Press of Kansas, 2009. - 224 p. - P. 2, 128.

7. Echr cases of Vinter and others v. the United Kingdom (Applications nos. 66069/ 09 and 130/10 and 3896/10) - 17 January 2012.

8. Уголовный кодекс Российской Федерации. - М. : Кодекс, 2013. - Ст. 79.

9. Конституційний суд ФРН визнав незаконним превентивне ув'язнення // Закон і бізнес [Електронний ресурс]. - Режим доступу: http://zib.com.ua/ua/3239volyu_zekam.html.

10. Echr case of Del Rho prada v. Spain (Application no. 42750/09) - 21 October 2013.

\section{А н о т а ц я я}

Туляков В. О. Тенденції кримінальної політики України та деякі інститути сучасного законодавства. - Стаття.

У статті мова йде про існування основних тенденцій кримінально-правової політики України: гуманізації відповідальності та таксономії кримінальних правопорушень. Зроблено висновок щодо структури теоретичної моделі майбутнього Кримінального кодексу та деяких заходів кримінально-правового впливу.

Ключові слова: кримінальна політика, криміналізація, кримінально-правові заходи, спеціальна конфіскація, помилування.

\section{А н н о т а ц я}

Tyляков B. A. Тенденции уголовной политики Украины и отдельные институты современного законодательства. - Статья.

В статье речь идет о существовании основных тенденций уголовно-правовой политики современности: гуманизации ответственности и таксономии криминальных правонарушений. Сделаны выводы о структуре теоретической модели будущего Уголовного кодекса и характеристиках отдельных видов уголовно-правовых мер.

Ключевые слова: уголовная политика, криминализация, уголовно-правовые меры, специальная конфискация, помилование.

\section{S u m m a r y}

Tulyakov $V$. Ukrainian criminal policy tendencies and separate institutes of modern legislation. - Article.

Main tendencies of modern criminal policy as taxonomy of criminal delicts and humanization of responsibility are analyzed in this article. Theoretical model of new Criminal code and separate types of criminal measures are proposed.

Keywords: criminal policy, criminalization, criminal-legal measures, special confiscation, mercy. 